\title{
Synthesis, spectral characterization, antimicrobial, DNA interactions and molecular modeling studies of metal complexes of 1, 3-benzothiazole carbohydrazone
}

\author{
KUNCHE SUDEEPA $^{\mathrm{a}}$, NAGULA NARSIMHA ${ }^{\mathrm{b}}$, BOINALA APARNA ${ }^{\mathrm{b}}$, SIVAN SREEKANTH ${ }^{\mathrm{a}}$, \\ A V APARNA ${ }^{\mathrm{a}}$, MUDAVATH RAVI ${ }^{\mathrm{b}}$, JAHEER MOHMED ${ }^{\mathrm{b}}$ and CH SARALA DEVI ${ }^{\mathrm{b}, *}$ \\ ${ }^{a}$ Department of Chemistry, Nizam College, Osmania University, Hyderabad, Telangana 500 001, India \\ ${ }^{b}$ Department of Chemistry, Osmania University, Hyderabad, Telangana 500 007, India \\ E-mail: dr_saraladevich@yahoo.com
}

MS received 4 October 2017; revised 19 January 2018; accepted 20 February 2018; published online 4 May 2018

\begin{abstract}
The compound $\mathrm{N}^{\prime}$-[(Z)-furan-2-ylmethylidene]-1,3-benzothiazole-2-carbohydrazone (FMBC) and its $\mathrm{Cu}$ (II), Ni (II) and Zn (II) complexes were synthesized and characterized by Mass, FT-IR, NMR, elemental analysis, TGA, ESR and SEM-EDX. Based on spectro-analytical data, geometries have been assigned to the metal complexes in which the FMBC acted as bidentate chelate in its mono dissociated form $(\mathrm{pKa}=$ 10.56). HyperChem 7.5 software was used for quantum chemical calculations using semi-empirical method. The eigenvalues of frontier orbitals and their corresponding contour maps of HOMO and LUMO for the title compound were computed by means of single point PM3 method. DNA binding of the synthesized complexes with calf thymus DNA was studied by spectrophotometry, fluorescence and viscosity techniques. From the experimental results, it is found that the complexes bind effectively to CT-DNA through an intercalative mode. Molecular docking studies with host DNA moiety inferred corroborative results for binding affinity of the compounds in accordance with experimental data. $\mathrm{IC}_{50}$ values calculated from the cytotoxicity studies carried out on HeLa cell line by MTT assay inferred obviously enhanced activity of the metal complexes over unbound free ligand. The candidate compounds screened for antimicrobial activity against bacterial species Bacillus, Escherichia coli, Staphylococcus, Pseudomonas and fungal species Sclerotium rolfsii and Macrophomina phaseolina signified greater potency of metal complexes over free carbohydrazone ligand.
\end{abstract}

Keywords. Hydrazone; Hyperchem; DNA binding; fluorescence; viscosity; cytotoxicity; docking.

\section{Introduction}

Transition metal complexes of carboxy hydrazones with $\mathrm{N}$ and $\mathrm{O}$ donor atoms have attracted considerable attention due to their inherent stability ${ }^{1}$ and various biological activities such as antimicrobial, DNA cleavage and cytotoxicity properties. ${ }^{2,3}$ Copper complexes of hydrazones could inhibit in vitro tumor cell growth with more pronounced cytotoxic activity compared to other metal complexes and corresponding free ligand in respective systems. ${ }^{4}$ Majority of the transition metal complexes interact with DNA through non-covalent binding modes by intercalation, groove binding or electrostatic interaction. ${ }^{5}$ The most important binding mode is intercalation, ${ }^{6}$ where the molecules intercalate

\footnotetext{
*For correspondence
}

between the base-pairs of the double helix DNA forming $\pi-\pi$ overlapping interactions, simultaneously lengthening and unwinding the DNA helix. ${ }^{7}$ The search for novel DNA binding agents to fight against cancer is one of the most important field in cancer research. ${ }^{8}$ There is an increasing prominence and evergreen curiosity in the field of metal containing drugs that bind to DNA. It is an established fact that benzothiazole derivatives contain extended $\pi$-delocalized systems which are capable of binding to DNA molecules via $\pi-\pi$ interaction and therefore exhibit various biological activities like antitumor, antiviral, anti-proliferative, anticancer, antimicrobial, anthelmintic, antidiabetic, anti-inflammatory and antimalarial properties. ${ }^{9-20}$

In view of the above applications cited in literature, the present study focuses on synthesis of 

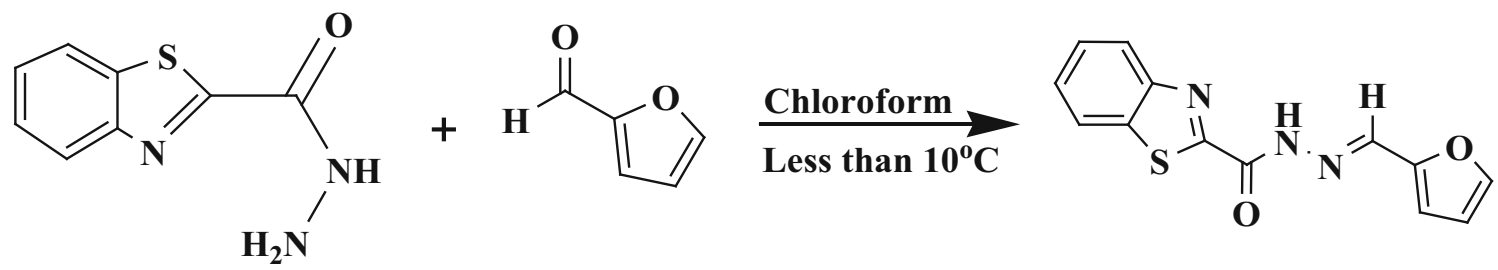

Scheme 1. Synthesis of FMBC

$\mathrm{N}^{\prime}$-[(Z)-furan-2-ylmethylidene]-1,3-benzothiazole-2carbohydrazone (FMBC) and its metal complexes. The structural aspects of FMBC and its $\mathrm{Cu}(\mathrm{II}), \mathrm{Ni}(\mathrm{II})$ and $\mathrm{Zn}$ (II) complexes have been studied employing spectroanalytical techniques. The interaction of the complexes with CT DNA was investigated in vitro by UV-Visible absorption and indirectly through the evaluation of the ethidium bromide (EB) displacing ability by the complexes examined by fluorescence emission. Molecular docking studies were carried out to support the experimentally evaluated binding interactions of these metal complexes with DNA. The potential of the complexes to act against certain microorganisms and as anticancer agents on human cervical cancer cell lines were also examined.

\section{Experimental}

\subsection{Materials}

All chemicals used were of Analytical Reagent (AR) Grade. MTT [3-(4, 5-dimethylthiazol-2-yl)-2, 5-diphenyltetrazolium bromide], trypsin, EDTA and Phosphate Buffered Saline (PBS) were purchased from Sigma Chemicals. The other materials purchased were Fetal Bovine Serum (FBS) from Gibco, Calf-thymus DNA (CT-DNA) $(50 \mu \mathrm{g} / \mathrm{test})$ from Bangalore genei; Bangalore and HeLa (Cervical cancer) cell lines from NCCS, Pune.

\subsection{Physical methods}

The mass spectral data was collected on Agilent Single Quad Mass Spectrometer using Electrospray Ionization (ESI-MS), IR spectra using Shimadzu- IR Prestige 21 Spectrophotometer using $\mathrm{KBr}$ disc in the range $200-4000 \mathrm{~cm}^{-1}$. NMR spectra were recorded on Bruker WH (270 MHz) spectrometer using $\mathrm{CDCl}_{3}$ and DMSO. The $\mathrm{pH}$ measurements were made using a digital ELICO electronic model LI120 pH meter in conjunction with a combined glass and calomel electrodes. ESR spectra were recorded on JES - FA200 ESR Spectrometer with $\mathrm{X}$-band at $77 \mathrm{~K}$. Thermal analyses were carried out using Shimadzu TGA-50H in nitrogen atmosphere, SEM images were recorded in INCA EDX analyser and the elemental analyses of compounds were carried out on Perkin-Elmer 240C elemental analyzer. The melting points were determined with
Polmon apparatus (Model No. MP-90). Absorption spectra were recorded on SHIMADZU160A UV-Visible spectrophotometer using $1 \mathrm{~cm}$ quartz micro cuvettes. Fluorescence spectra were recorded on a JASCO FP-8500 spectrofluorometer.

The computational studies were carried out by using HyperChem 7.5 software. The structure of the ligand molecule was built using HyperChem 7.5 software in its molecular and ionized forms and the geometry optimization was carried out using semi-empirical PM3 method. ${ }^{21-23}$ As the frontier molecular orbital energies are significant parameters for the prediction of the reactivity of a chemical compounds, in the present investigation the values of eigenvalues of the highest occupied molecular orbitals ( $\left.\mathrm{E}_{\mathrm{HOMO}}\right)$ and lowest unoccupied molecular orbitals $\left(\mathrm{E}_{\mathrm{LUMO}}\right)$ of the title compound were computed. To understand orientation of frontier orbitals and their localized regions, the corresponding orbital contour maps were analysed. Molecular docking studies were carried out with metal complexes constructed and optimized in ChemDraw software. Crystal structure of DNA was downloaded from protein data bank ${ }^{24}$ (www.rcsb.org) pdb id: $1 \mathrm{~N} 37(\mathrm{AGACGTCT})_{2}$, which was prepared by protein preparation wizard applying OPLS 2005 force field in Schrodinger suite. A grid was prepared around the intercalation site by selecting the co-crystallized ligand. Metal complexes were docked into DNA intercalation site using Autodock 4.2 Software. ${ }^{25}$ Molecular interaction diagrams are obtained from Python Molecular Viewer (PMV).

\subsection{Synthesis of $N^{\prime}-[(Z)$-furan-2-yl-methylidene]-1,3- benzothiazole-2-carbohydrazone (FMBC)}

To a suspension of $2.59 \mathrm{mmol}(500 \mathrm{mg})$ benzothiazole2-carboxyhydrazide (BTCH) ${ }^{26,27}$ in $15 \mathrm{~mL}$ of chloroform, $0.0025 \mathrm{mmol}(248 \mathrm{mg}$ ) of furan-2-carbaldehyde was added and this mixture was kept in cold condition for 5-7 h. Excess solvent was distilled off and the resulting solid was recrystallized from methanol to give yellow coloured compound. Purity of the compound was checked by TLC using acetone: methanol (1:1) mobile phase. The melting point was found to be $226^{\circ} \mathrm{C}$ (Scheme 1).

2.3a Ligand: L: M.p.: $226^{\circ} \mathrm{C} ; \mathrm{C}_{13} \mathrm{H}_{9} \mathrm{~N}_{3} \mathrm{O}_{2} \mathrm{~S}$ : Anal. Found: C, 57.55; H, 3.34; N, 15.49\%; Calc.: C,55.22; H, $3.05 ; \mathrm{N}, 14.97 \%$. IR (KBr, v /cm-1): v (NH) 3400, v (C-H) 3298-2897, $v(\mathrm{C}=\mathrm{O})$ of $-\mathrm{CONH} 1697$ (Figures $\mathrm{S} 1$ and $\mathrm{S} 2$ in Supplementary Information). ${ }^{1} \mathrm{H}-\mathrm{NMR}\left(270 \mathrm{MHz}, \mathrm{CDCl}_{3}\right.$, TMS): $\delta 7.6-8 \mathrm{ppm}(\mathrm{m}, 7 \mathrm{H}) ; \delta 8.3 \mathrm{ppm}(\mathrm{s}, 1 \mathrm{H}) ; \delta 10 \mathrm{ppm}$ 
(s, 1H). ${ }^{13} \mathrm{C}$ NMR (100 MHz, $\mathrm{CDCl}_{3}$ TMSO): $\delta 122.8,124.9$, $126,137,152.3,156.2,158.4,164$ ppm (Figure S3 in Supplementary Information) ESI MS (m/z): Calc.: 271. Found 272 $[\mathrm{M}+1]$.

\subsection{Synthesis of metal complexes}

To hot ethanolic solution of FMBC ( $2 \mathrm{mmol}), 1 \mathrm{mmol}$ of metal chloride of ( $\mathrm{M}=\mathrm{Cu}(\mathrm{II}), \mathrm{Ni}(\mathrm{II}), \mathrm{Zn}(\mathrm{II}))$ was added and the reaction mixture was refluxed on water bath for 4-8 h maintaining the $\mathrm{pH}$ in the range $4.5-6.5$ to enable complex formation. The precipitated complex was filtered off, washed with anhydrous ethanol and dried in vacuum at room temperature. All the metal complexes are coloured and stable to air and moisture.

2.4a $\left[C u(F M B C)_{2}\right]: \quad$ (1): M.p.: $298^{\circ} \mathrm{C} ; \mathrm{C}_{26} \mathrm{H}_{20} \mathrm{~N}_{6} \mathrm{O}_{6} \mathrm{~S}_{2}$ $\mathrm{Cu}$ : Anal. Found: C, 48.78; H, 3.15; N, 13.13;.Cu; 9.93\%. Calc.: C, 47.22; H, 3.1; N, 8.77; Cu, 9.13\%. IR ( $\mathrm{KBr}$, $\left.\nu / \mathrm{cm}^{-1}\right): \nu_{(\mathrm{C}=\mathrm{O})} 1633, \nu(\mathrm{C}=\mathrm{N}) 1479, \nu_{(\mathrm{OH} / \mathrm{H} 2 \mathrm{O})} 3435$, $\nu_{(\mathrm{M}-\mathrm{N})} 364, v_{(\mathrm{M}-\mathrm{O})} 509 \mathrm{ESR}: \mathrm{g} \|=2.10, g \perp=2.0617$. ESIMS (m/z):Calc.: 639. Found: $640[\mathrm{M}+1]$.

2.4b $\quad\left[N i(F M B C)_{2}\right]: \quad$ (2): M.p.: $297^{\circ} \mathrm{C} ; \mathrm{C}_{26} \mathrm{H}_{20} \mathrm{~N}_{6} \mathrm{O}_{6} \mathrm{~S}_{2}$ Ni: Anal. Found: C, 49.15; H, 3.14; N, 13.09; Ni; 9.24\%. Calc.: C, 48.64; H, 3.11; N, 12.86; Ni, 9.04\%. IR (KBr, $\left.\nu / \mathrm{cm}^{-1}\right): \nu(C=O) 1631, \nu_{(C=N)} 1458, \nu_{(O H / H 2 O)} 3365$, $\nu_{(\mathrm{M}-\mathrm{N})} 374 v_{(\mathrm{M}-\mathrm{O})} 495$. ESI-MS (m/z): Calc.: 634. Found: $635[\mathrm{M}+1]$.

2.4c $\quad\left[\mathrm{Zn}(F M B C)_{2}\right]: \quad$ (3): M.p.:295 ${ }^{\circ} \mathrm{C} ; \mathrm{C}_{26} \mathrm{H}_{20} \mathrm{~N}_{6} \mathrm{O}_{6} \mathrm{~S}_{2}$ Zn: Anal. Found: C, 48.64; H, 3.14; N, 13.09; Zn; $10.19 \%$. Calc.: C, 48.32; H, 3.10; N, 12.98; Zn, 9.98\%. IR ( $\mathrm{KBr}$, $\left.\nu / \mathrm{cm}^{-1}\right): \nu_{(C=O)} 1612, \nu_{C=N} 1465, \nu_{(O H / H 2 O)} 3325$, $\nu_{(\mathrm{M}-\mathrm{N})} 364 \nu_{(\mathrm{M}-\mathrm{O})} 557$.ESI-MS (m/z): Calc.: 641. Found: $642[\mathrm{M}+1]$.

\subsection{Biological studies}

2.5a Antibacterial and antifungal activity: The synthesized hydrazone FMBC and its metal complexes were screened for their in vitro antibacterial activity against gram positive bacteria viz., Bacillus Subtilis and Staphylococcus and gram negative bacteria viz., Escherichia and Pseudomonas. Antibacterial activity was tested by standard agar diffusion method. Fresh bacterial culture having $5 \times 10^{-5}$ colonies was mixed with nutrient agar medium and poured into plates. Wells were made in the cooled agar plates $(1 \mathrm{~cm})$ and $100 \mu \mathrm{L}$ sample solution prepared by dissolving $5 \mathrm{mg}$ of compound in DMSO was loaded in the respective well. Then the activity was observed after incubation period of $24-48 \mathrm{~h}$ at $37^{\circ} \mathrm{C}$. The diameter of zone for inhibition was recorded in units of millimetres. In vitro antifungal activity of the synthesized hydrazone and its metal complexes was tested against Macrophomina phaseolina and Sclerotium rolfsii. Potato Dextrose Agar media was prepared and the fungal plugs were placed in the center of the plate and the compounds were put in the wells surrounding the plug and the zone of inhibition was measured after $72 \mathrm{~h}$.

2.5b DNA-binding experiments: Absorption spectra measurements: Absorption titrations were performed keeping the concentration of the metal complex constant $(5 \mu \mathrm{M})$, while varying the concentration of CT-DNA via steady addition of CT-DNA $(0-5 \mu \mathrm{M})$. The absorption spectra were recorded in the range of $200-800 \mathrm{~nm}$.

Fluorescence spectra measurements: To ascertain binding ability of the compound, assay with ethidium bromide (EB) was carried out. As ethidium bromide is known to exhibit emission property when it binds with DNA, a buffer solution containing DNA $(36 \mu \mathrm{M})$ and $\mathrm{EB}(36 \mu \mathrm{M})$ was titrated with the metal complex $(0-36 \mu \mathrm{M})$. The fluorescence spectra of the complexes bound to DNA were recorded at excitation wavelength of $480 \mathrm{~nm}$.

Viscosity: To investigate the mode of interaction between binding of metal complexes with CT-DNA, viscosity experiments were performed with an Ostwald viscometer immersed in a thermostatic water bath maintained at $303 \pm 0.1 \mathrm{~K}$. Titrations were performed for complexes under study by introducing each complex $(0.5-3.5 \mu \mathrm{M})$ into the CT-DNA solution $(5.0 \mu \mathrm{M})$ present in the viscometer. Flow time was measured with a digital stop watch, three times for each sample and an average flow time was calculated.

\subsection{Cytotoxicity}

The cell lines were cultured in DMEM (Dulbecco's modified Eagles medium), which was supplemented with $10 \%$ heat inactivated Fetal BovineSerum (FBS) and 1\% Antibiotic Antimycotic 100X solution. The cells were seeded at a density of approximately $5 \times 10^{3}$ cells/well in a 96-well flat-bottom micro plate and maintained at $37{ }^{\circ} \mathrm{C}$ in $95 \%$ humidity and $5 \% \mathrm{CO}_{2}$ for overnight, the sample solution in varying concentrations $(200,100,50,25,12.5,6.25 \mu \mathrm{g} / 300 \mathrm{~mL})$ were incubated for $48 \mathrm{~h}$. The cells in well were washed twice with phosphate buffer solution, and $20 \mu \mathrm{L}$ of the MTT staining solution $(5 \mathrm{mg} / \mathrm{mL}$ in phosphate buffer solution) was added to each well and plate was incubated at $37^{\circ} \mathrm{C}$. After $4 \mathrm{~h}$, $100 \mu \mathrm{L}$ of dimethyl sulfoxide (DMSO) was added to each well to dissolve the formazan crystals. Standard anticancer drug Paclitaxel $0.3 \mu \mathrm{M} / \mathrm{mL}$ was employed and absorbance of test solutions was recorded at $570 \mathrm{~nm}$ using micro plate reader.

\section{Results and Discussion}

\subsection{Spectral characterization of $F M B C$}

3.1a Mass: The mass spectra of the FMBC (Figure S1 in Supplementary Information) recorded a dominant base peak at $\mathrm{m} / \mathrm{z} 272$, which is in accordance with the expected $[\mathrm{M}+1]^{+}$peak. 


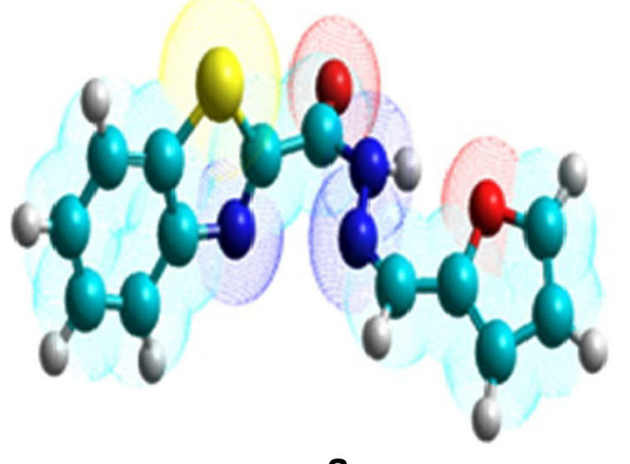

a

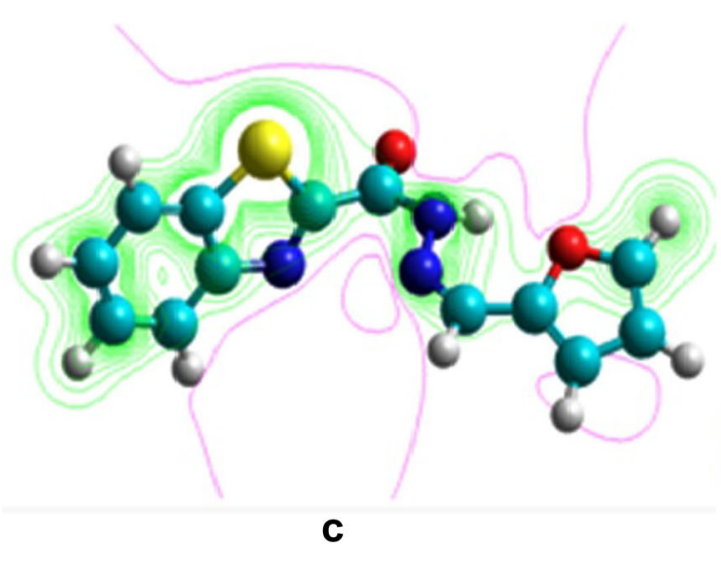

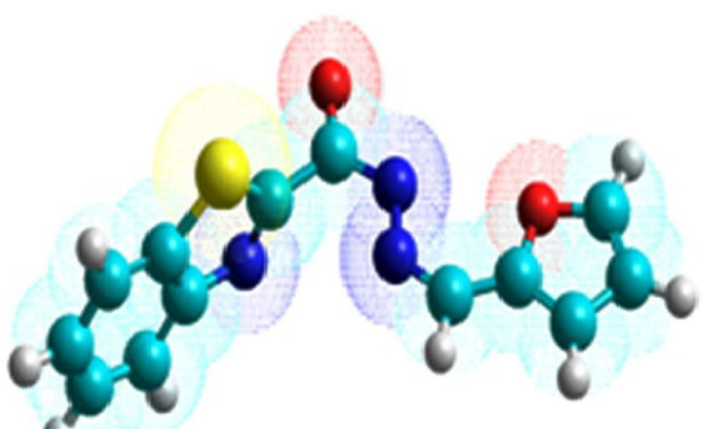

b

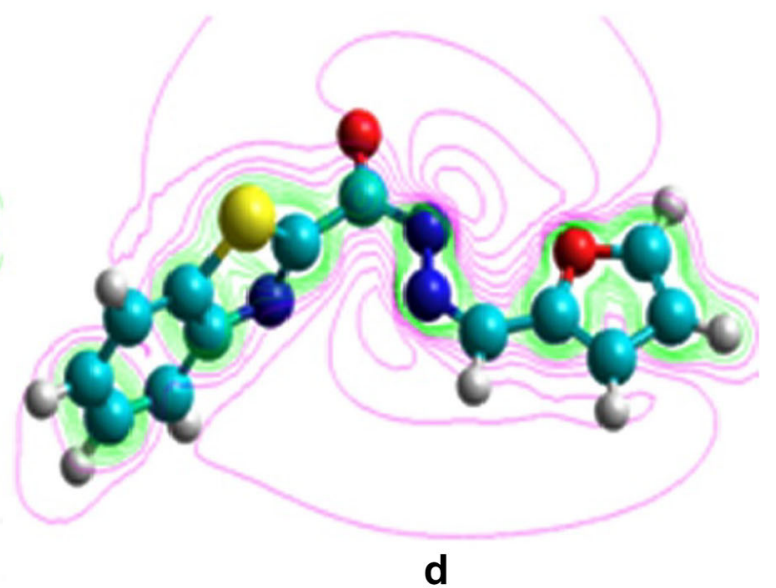

Figure 1. Geometry-optimised structures of FMBC in molecular and ionic forms (a, b), and electrostatic potential contour maps in molecular and ionized forms $(\mathbf{c}, \mathbf{d})$.

3.1b IR: The IR spectrum of FMBC (Figure S2 in Supplementary Information) exhibited bands at $3400 \mathrm{~cm}^{-1}$ and $3298-2897 \mathrm{~cm}^{-1}$ corresponding to amide $\nu(\mathrm{NH})$ and aromatic $\nu(\mathrm{C}-\mathrm{H})$ stretching vibrations, respectively. The presence of a sharp intense band at $1697 \mathrm{~cm}^{-1}$ is attributable to $v(\mathrm{C}=\mathrm{O})$ of $-\mathrm{CONH}$ group. The bands at $1573 \mathrm{~cm}^{-1}$ and $1512 \mathrm{~cm}^{-1}$ indicate the stretching frequencies of azomethine group of hydrazone moiety present in $\mathrm{FMBC}$ and $\mathrm{C}=\mathrm{N}$ bond of thiazole ring.

3.1c NMR: The NMR data of FMBC is recorded in $\mathrm{CDCl}_{3}$ (Figure S3 in Supplementary Information). The aromatic protons are observed in the region of $\delta 7.6-$ $8 \mathrm{ppm}(\mathrm{m}, 7 \mathrm{H})$. Azomethine proton ${ }^{28}$ is observed at $\delta 8.3 \mathrm{ppm}(\mathrm{s}, 1 \mathrm{H})$ and peak at $\delta 10 \mathrm{ppm}(\mathrm{s}, 1 \mathrm{H})$ corresponds to $-\mathrm{NH}$ proton, and is further confirmed by $\mathrm{D}_{2} \mathrm{O}$ exchange, which disappeared on deuteration. ${ }^{13} \mathrm{C}$ NMR spectrum of FMBC exhibits signals in the region $\delta 122-128$ ppm and $138-158$ ppm corresponding to aromatic carbons of benzothiazole moiety and furan ring, respectively. The signal at $\delta 164 \mathrm{ppm}$ corresponds to carbonyl $(\mathrm{C}=\mathrm{O})$ carbon. The experimental spectral data is in accordance with the structure of the title compound. 3.1d Equilibrium studies: To comprehend the chelation properties of the FMBC, an attempt is made to study its potential donor sites that bind with metal ions. The dissociation constant values were calculated using Irving-Rossetti titration curves (Figure S4(a) in Supplementary Information). From the titration data, dissociation constants were calculated from the linear plots of $\log \left[\left(1-\bar{n}_{A}\right) / \bar{n}_{A}\right]$ vs $\mathrm{pH}$ ) (Figure $\mathrm{S} 4$ (b) in Supplementary Information). The results indicated the presence of one dissociable proton corresponding to $\mathrm{NH}$ proton with $\mathrm{pKa}$ of 10.56 .

\subsection{Computational studies}

Molecular modeling studies were carried out with title compound using Hyperchem 7.5 software. The molecular structure of title compound was built in both molecular and its ionic forms (Figure 1) and its geometry was optimized by employing Semi-empirical PM3 to generate molecular orbitals and electrostatic potential contour maps (Figure 2). The energy difference between the HOMO and LUMO frontier orbitals in ionic and molecular forms (Table 1) infers relatively more labile 


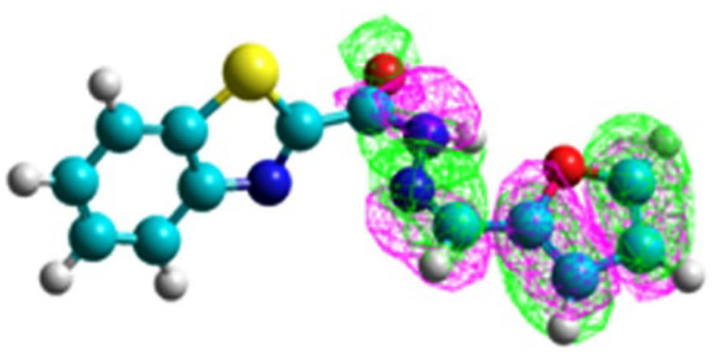

a

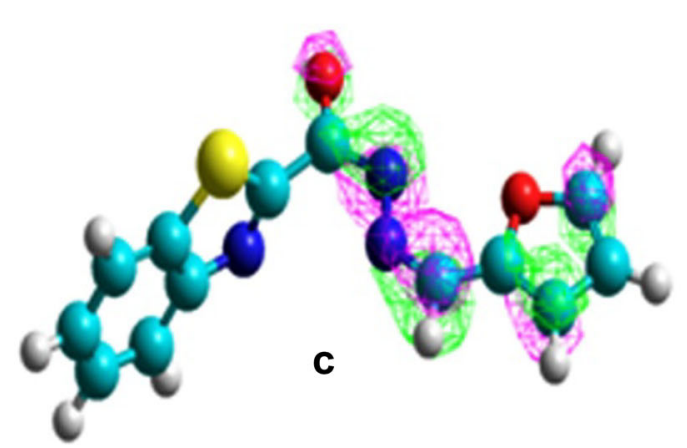

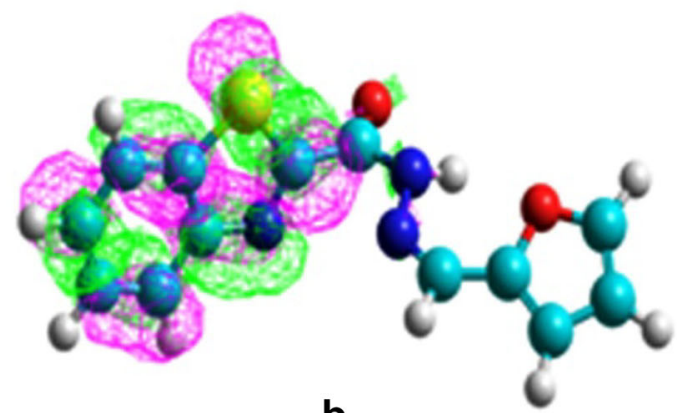

b

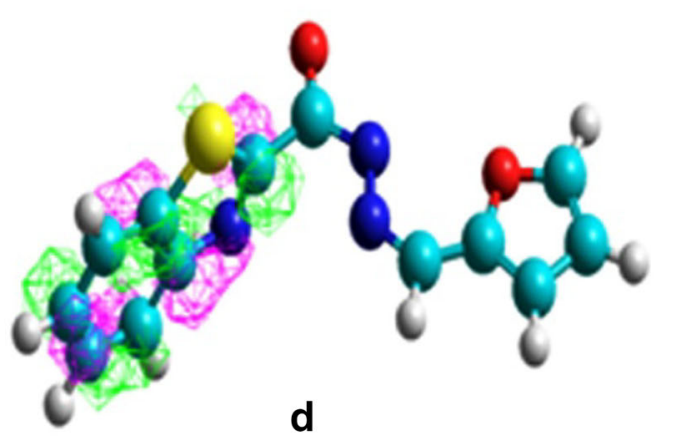

Figure 2. Contour maps of HOMO, LUMO frontier orbitals of FMBC in molecular (a and b) and ionized forms (c and $\mathbf{d})$.

Table 1. Properties of Frontier Molecular Orbitals.

\begin{tabular}{lccc}
\hline FMBC & Eigenvalues $_{\mathrm{HOMO}}$ & Eigenvalues $_{\mathrm{LUMO}}$ & $\mathrm{E}_{\mathrm{HOMO}}-\mathrm{E}_{\mathrm{LUMO}}$ \\
\hline Molecular form & $-9.10 \mathrm{eV}$ & $-0.87 \mathrm{eV}$ & $8.23 \mathrm{eV}$ \\
Ionic form & $-3.87 \mathrm{eV}$ & $+2.04 \mathrm{eV}$ & $5.91 \mathrm{eV}$ \\
\hline
\end{tabular}

Table 2. Mass spectral data, C H N data and molar conductivity.

\begin{tabular}{|c|c|c|c|c|c|c|c|c|}
\hline \multirow[t]{2}{*}{ Sl. No } & \multirow[t]{2}{*}{ Compound } & \multirow[t]{2}{*}{ Colour } & \multirow[t]{2}{*}{$\mathrm{m} / \mathrm{z}$} & \multicolumn{4}{|c|}{ Analysis: Found (Calc.) \% } & \multirow[t]{2}{*}{$\Omega^{-1} \mathrm{~cm}^{2} \mathrm{~mol}^{-1}$} \\
\hline & & & & $\mathrm{C}$ & $\mathrm{H}$ & $\mathrm{N}$ & M & \\
\hline 1 & FMBC & Light yellow & 272 & $\begin{array}{c}57.55 \\
(55.35)\end{array}$ & $\begin{array}{c}3.34 \\
(3.25)\end{array}$ & $\begin{array}{c}15.49 \\
(15.37)\end{array}$ & - & - \\
\hline 2 & FMBC-Cu (II) & Yellowish brown & 640 & $\begin{array}{c}48.78 \\
(47.82)\end{array}$ & $\begin{array}{c}3.15 \\
(3.11)\end{array}$ & $\begin{array}{c}13.13 \\
(13.07)\end{array}$ & $\begin{array}{c}9.93 \\
(9.53)\end{array}$ & 3.1 \\
\hline 3 & FMBC-Ni (II) & Dark brown & 635 & $\begin{array}{c}49.15 \\
(48.84)\end{array}$ & $\begin{array}{c}3.14 \\
(3.11)\end{array}$ & $\begin{array}{c}13.09 \\
(12.96)\end{array}$ & $\begin{array}{c}9.24 \\
(9.14)\end{array}$ & 3.4 \\
\hline 4 & FMBC-Zn (II) & Yellow & 642 & $\begin{array}{c}48.64 \\
(48.42)\end{array}$ & $\begin{array}{c}3.14 \\
(3.10)\end{array}$ & $\begin{array}{c}13.09 \\
(12.98)\end{array}$ & $\begin{array}{l}10.19 \\
(9.98)\end{array}$ & 3.5 \\
\hline
\end{tabular}

nature of ionized form towards binding with metal ion for the formation of a complex. The lesser negative values of eigen values of orbitals which correspond to lower binding energy of electrons in HOMO frontier orbitals of ionic species signifies greater binding ability in ionized form rather than in molecular form. The contour maps of electrostatic potentials indicate the negative charge delocalization on nitrogen and oxygen atoms in both molecular and in ionized forms.

\subsection{Characterization of copper, nickel and zinc complexes of FMBC}

3.3a Mass: The analysed mass spectral data of the metal complexes are presented in Table 2. The mass spectral data of all the metal complexes (Figure 3) are in good agreement with the results of elemental analyses inferring the formation of 1: 2 metal complex in respective system. 
Cu-FMBC
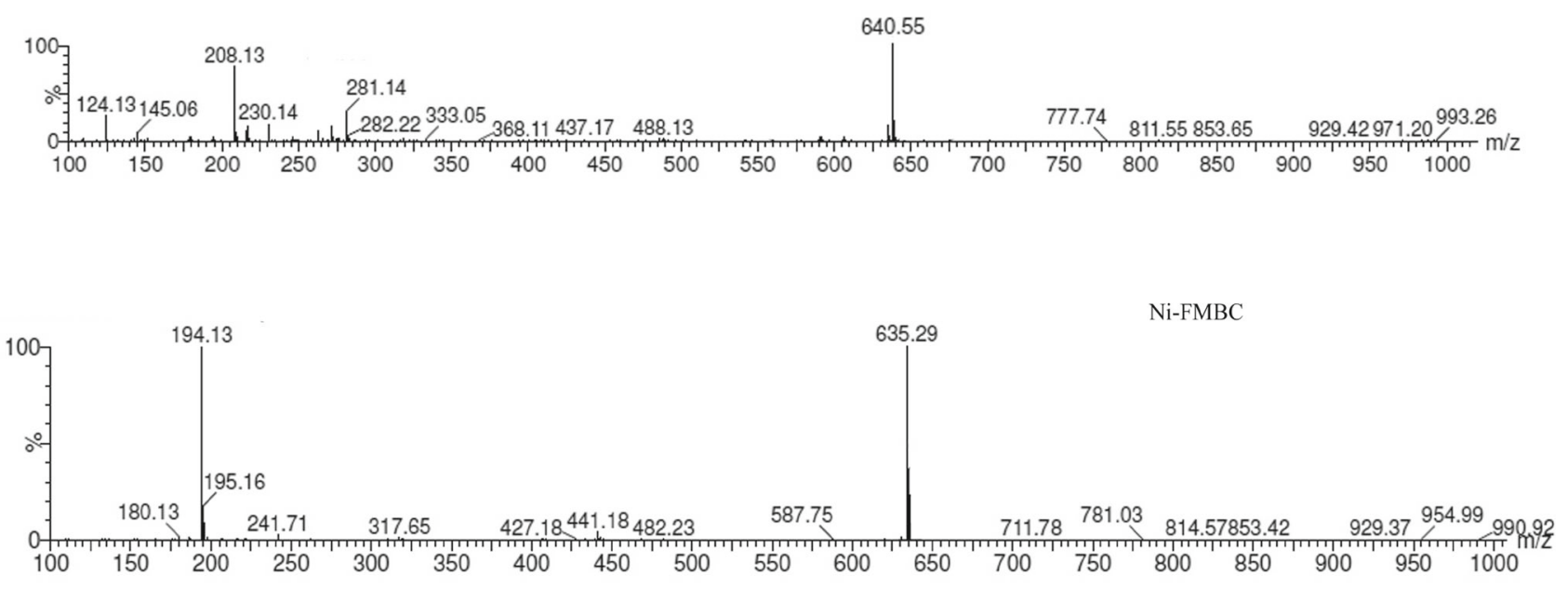

Zn-FMBC

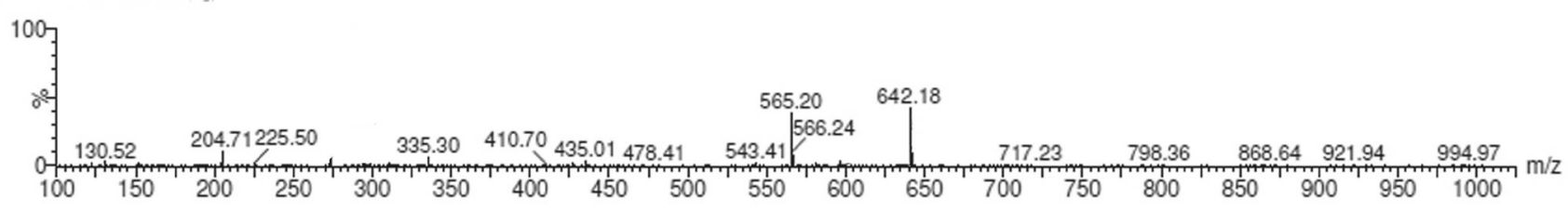

Figure 3. Mass Spectra of FMBC - Cu(II), Ni(II) and Zn (II) complexes.

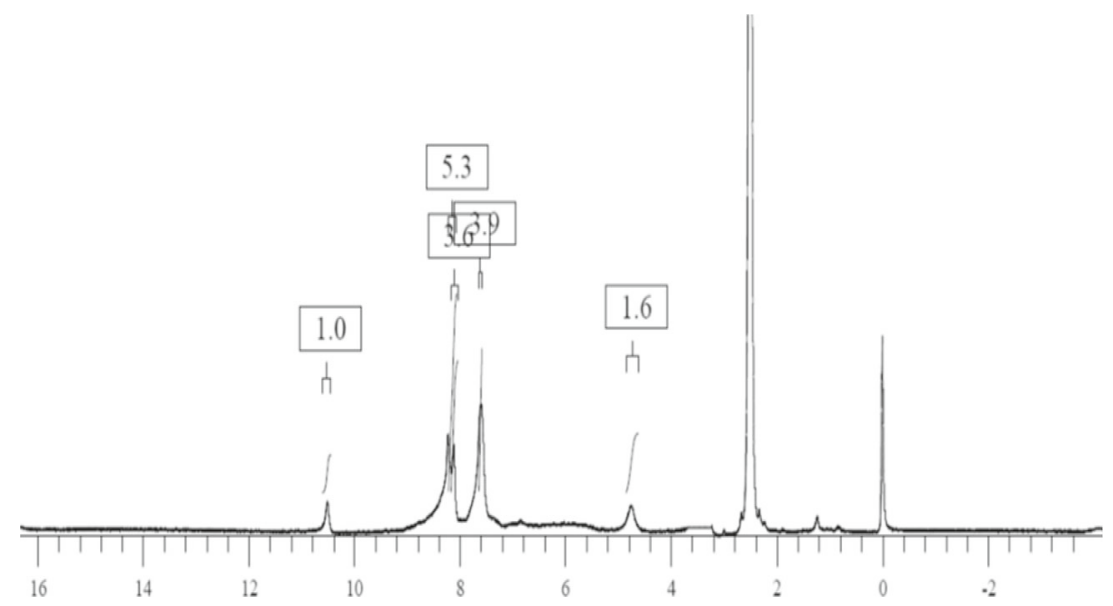

Figure 4. ${ }^{1} \mathrm{H}-\mathrm{NMR}$ Spectrum of FMBC- $\mathrm{Zn}(\mathrm{II})$.

The analytical data along with molar conductances of FMBC and its complexes are presented in (Table 2). The non-electrolytic nature of the complexes is evident from the low molar conductivities measured in DMSO.

3.3b NMR: The ${ }^{1} \mathrm{H}$ NMR of FMBC-Zn(II) complex (Figure 4) was recorded using DMSO-d6 as a solvent. The NMR spectrum of $\mathrm{Zn}$ (II) complex (Figure 4) showed peaks in the region of $\delta 4.5-8.0 \mathrm{ppm}$ assignable to the aromatic protons, while azomethine proton is at $10.5 \mathrm{ppm}$. A comparison of the NMR spectra of the free ligand and $\mathrm{Zn}(\mathrm{II})$ complex ${ }^{29}$ indicates downfield shift of azomethine proton, which is ascribable to electron donation from adjacent imine nitrogen to form dative bond with $\mathrm{Zn}(\mathrm{II})$. The peak of $\mathrm{NH}$ proton observed in the ligand disappeared in the complex spectrum because of deprotonation of amide proton through its enol form and subsequent binding of the ionized form with $\mathrm{Zn}$ (II) involving $\mathrm{O}$ and $\mathrm{N}$ as donor sites. 
Table 3. FT-IR $\left(\mathrm{cm}^{-1}\right)$ spectral data of FMBC and its metal complexes.

\begin{tabular}{lcccccc}
\hline Sl. No & Compound & $v_{\mathrm{C}=\mathrm{O}}$ & $v_{\mathrm{C}=\mathrm{N}}$ & $v_{\mathrm{OH} / \mathrm{H} 2 \mathrm{O}}$ & $v_{\mathrm{M}-\mathrm{N}}$ & $v_{\mathrm{M}-\mathrm{O}}$ \\
\hline 1 & FMBC & 1697 & 1512 & - & - & - \\
2 & FMBC- Cu (II) & 1633 & 1479 & 3435 & 364 & 509 \\
3 & FMBC- Ni (II) & 1631 & 1458 & 3365 & 374 & 495 \\
4 & FMBC- Zn (II) & 1612 & 1465 & 3323 & 364 & 557 \\
\hline
\end{tabular}

3.3c IR: The mode of binding in metal complexes is envisaged by comparing their IR spectra with the IR spectrum of the ligand (Table 3). The IR spectrum of the ligand showed bands at 1697 and $1573 \mathrm{~cm}^{-1}$ corresponding to $\nu \mathrm{C}=\mathrm{O}$ and $\nu \mathrm{C}=\mathrm{N}$. These bands were shifted to a lower wavenumber in all the complexes indicating participation of oxygen of the carbonyl group and azomethine nitrogen atoms in bonding. In the spectra of metal complexes (Figures S5-S7 in Supplementary Information) new bands appeared at $495-557 \mathrm{~cm}^{-1}$ and 364-374 $\mathrm{cm}^{-1}$ correspond to $\nu_{\mathrm{M}-\mathrm{O}}$ and $\nu_{\mathrm{M}-\mathrm{N}},{ }^{30,31}$ respectively. The broad bands in the region 3452$3435 \mathrm{~cm}^{-1}$ correspond to $\nu_{\mathrm{O}-\mathrm{H}}$ vibration indicating the presence of coordinated water molecules ${ }^{32}$ in all the complexes. The coordinated water is further confirmed by TGA data of the complexes.

3.3d Thermal analysis (TGA): To ascertain the thermal stability of metal complexes, thermo grams of each system was recorded (Figure S8 in Supplementary Information). In the present study, heating rate was suitably controlled at $10^{\circ} \mathrm{C} / \mathrm{min}$ under nitrogen atmosphere and the loss in weight is measured up to $1000^{\circ} \mathrm{C}$. $\mathrm{Cu}$ (II)FMBC complex displayed four stages of weight loss. The weight loss in the range of $150-200{ }^{\circ} \mathrm{C}$ indicates the loss of occluded water. The loss in the range of 220 $225^{\circ} \mathrm{C}$ and subsequent loss upto $300{ }^{\circ} \mathrm{C}$ correspond to loss of coordinated water molecule. ${ }^{33}$ The sudden weight loss in the region $310-390{ }^{\circ} \mathrm{C}$ is due to partial decomposition of ligand moiety and further gradual weight loss upto $1000{ }^{\circ} \mathrm{C}$ indicates maximum extent of decomposition of ligand leaving $30 \%$ of residual moiety.

The TG curve of Ni(II)-FMBC complex exhibited weight loss in the range of $150-200{ }^{\circ} \mathrm{C}$ indicating the loss of occluded water. The gradual decomposition of the ligand moiety in the region of $200-300{ }^{\circ} \mathrm{C}$, then subsequent sudden losses in the range of $310-390^{\circ} \mathrm{C}$ and $400-500{ }^{\circ} \mathrm{C}$ indicates partial decomposition of ligand. Further gradual weight loss upto $1000^{\circ} \mathrm{C}$ indicates maximum decomposition of ligand leaving $28 \%$ of residual moiety. The Zn (II)-FMBC showed weight loss in the region of 150 to $250{ }^{\circ} \mathrm{C}$ corresponding to weight loss of coordinated water. Then subsequent gradual loss in

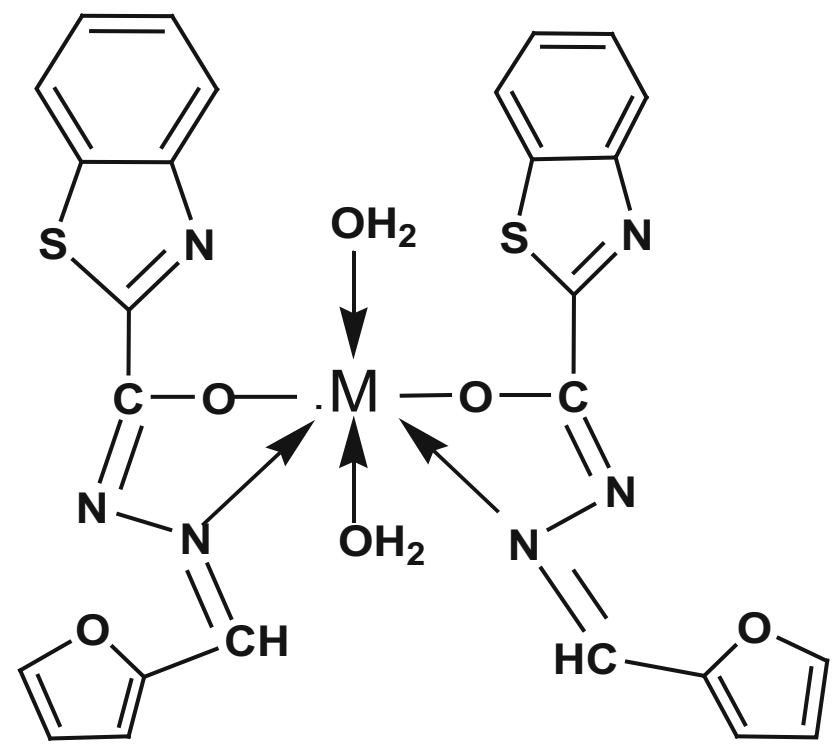

Figure 5. Structure of metal complex (M-FMBC) $(\mathrm{M}=\mathrm{Cu}$ (II), Ni (II) and $\mathrm{Zn}$ (II)).

the range of $250-400{ }^{\circ} \mathrm{C}$ and sudden loss upto $500{ }^{\circ} \mathrm{C}$ indicate partial decomposition of ligand. Further gradual weight loss upto $1000{ }^{\circ} \mathrm{C}$ indicates greater portion of decomposition of ligand moiety leaving $31 \%$ of residual moiety.

\subsection{SEM and EDX of FMBC and its complexes}

The SEM pictures (Figure S9 in Supplementary Information) of the ligand and its complexes under investigation showed information about the morphology of the compounds. The compounds under study exhibited different surface morphology. After complexation the change in morphology of the particles was observed. EDX spectra (Figure S10 in SI) indicated the elemental composition in FMBC and its complexes.

\section{$3.5 E S R$}

Information regarding the metal ligand bond covalency and the metal ion environment is obtained from ESR spectrum. The ESR of Cu(II)-FMBC (Figure S11 in Supplementary Information) was recorded at liquid 


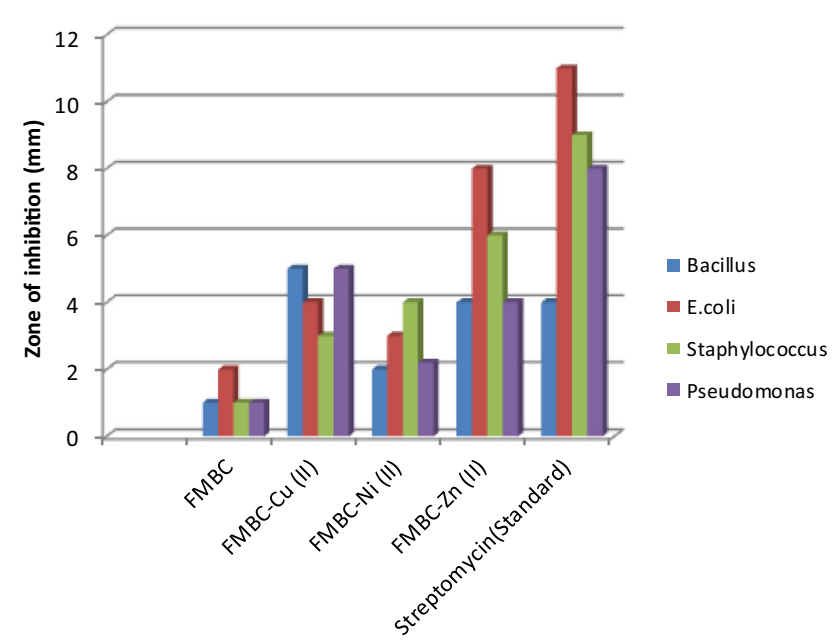

Figure 6. Zone of Inhibition of FMBC and metal complexes.

nitrogen temperature (X-band $77 \mathrm{~K}$ ) in DMSO solution, exhibited two $g$ values corresponding to $g \|$ and $g \perp$ at 2.10 and 2.0617. The value of g\|l which is greater

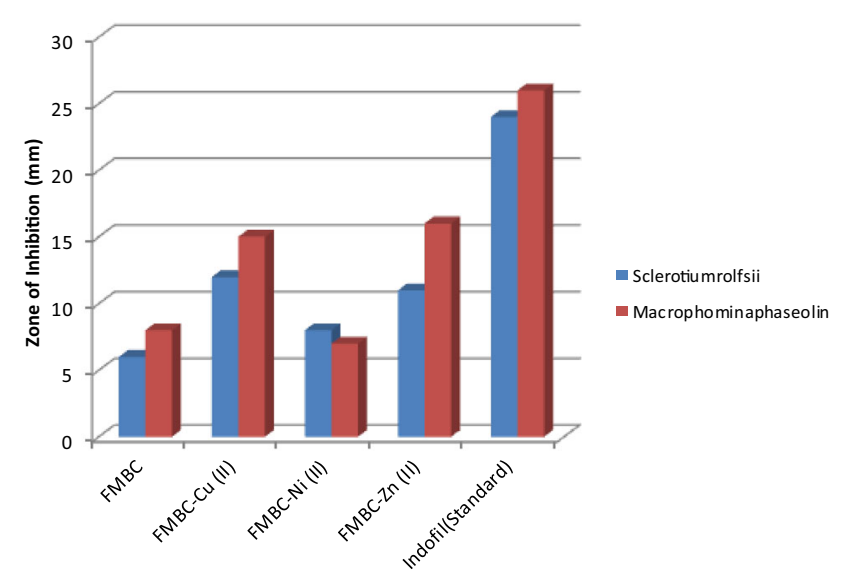

Figure 7. Zone of Inhibition of FMBC and metal complexes.

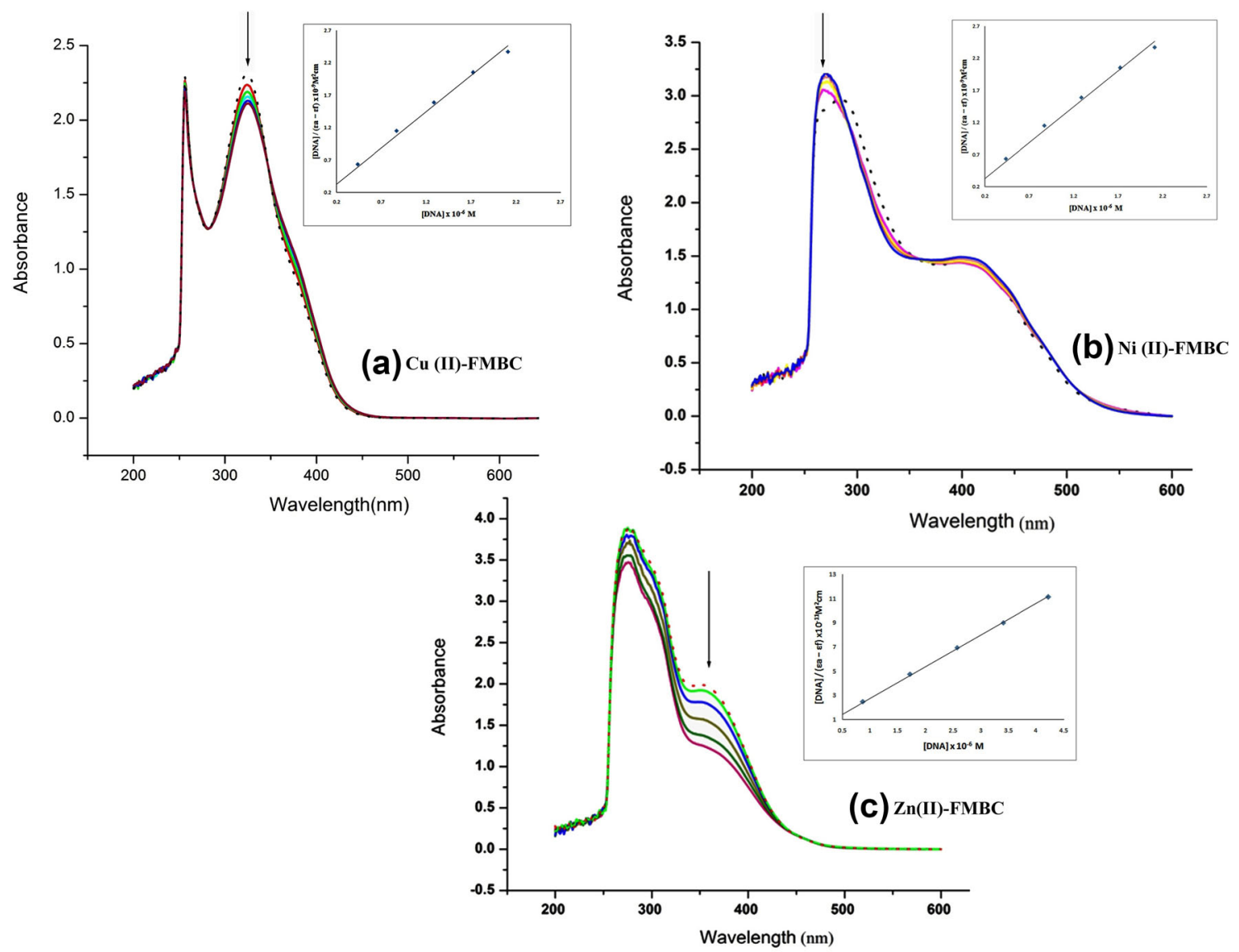

Figure 8. UV-Vis absorption spectra of complexes. (a) $\mathrm{Cu}$ (II)-FMBC, (b) $\mathrm{Ni}$ (II)-FMBC and (c) $\mathrm{Zn}$ (II)-FMBC in the absence (dashed line) and presence (solid line) of increasing amount of CT-DNA. $([$ complex $]=5 \mu \mathrm{M}$, [DNA] $=0-5 \mu \mathrm{M})$ in TrisHCl buffer $(\mathrm{pH} 7.2)$ at $25^{\circ} \mathrm{C}$. Arrow $(\downarrow)$ shows the hypochromic and red shift upon increasing CT-DNA concentration. Inset: linear plot for the calculation of

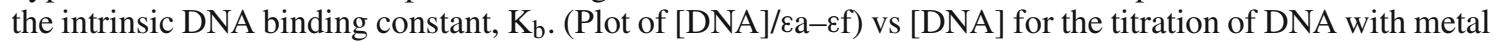
complexes). 

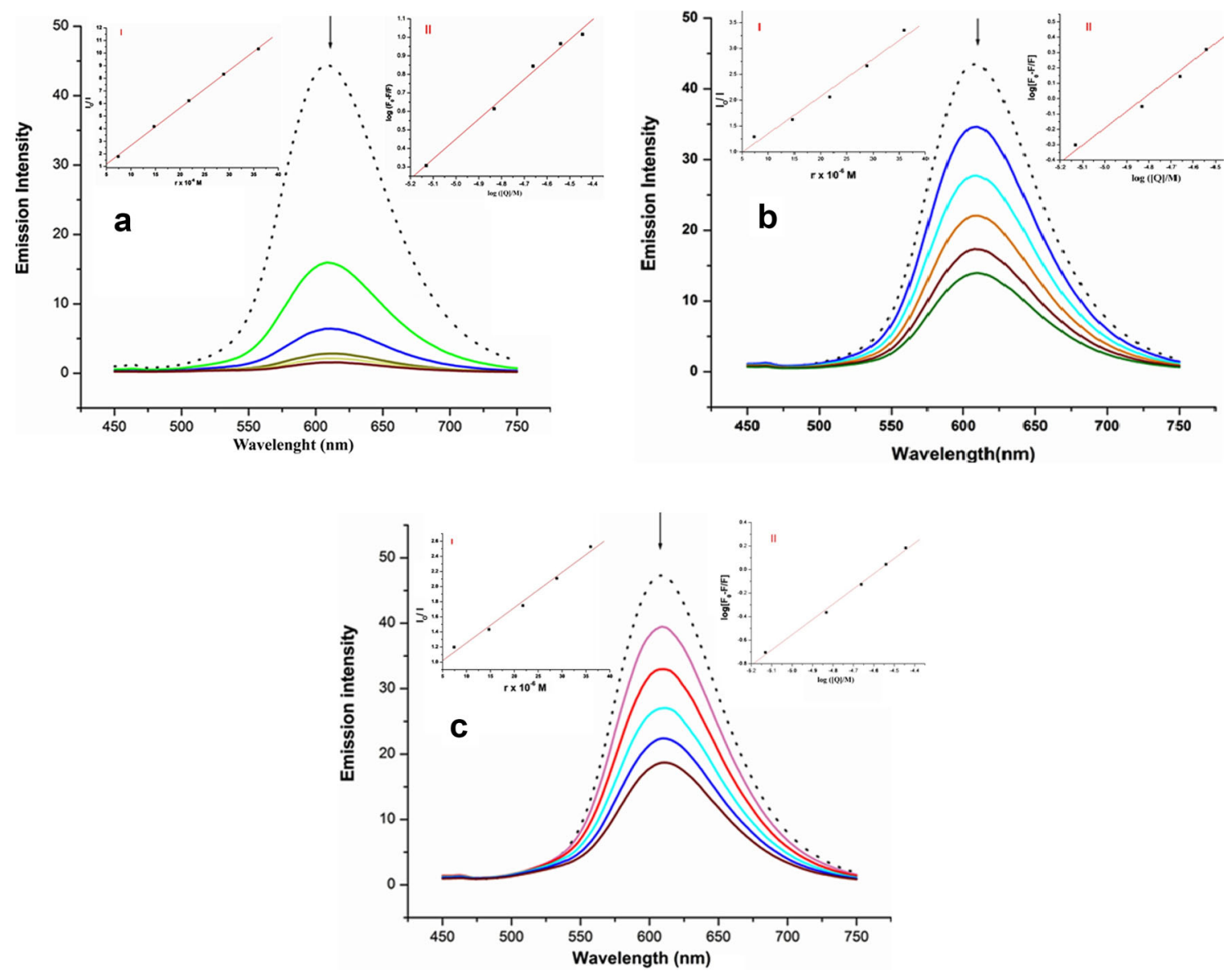

Figure 9. Quenched Fluorescence spectra of DNA $(36 \mu \mathrm{M})$ bound to EB $(36 \mu \mathrm{M})$ in the absence (dashed line) and presence (solid line) of increasing concentration of complexes $(0-36 \mu \mathrm{M})$ at $480 \mathrm{~nm}$. (a) $\mathrm{Cu}(\mathrm{II})-\mathrm{FMBC},(\mathbf{b}) \mathrm{Ni}(\mathrm{II})-\mathrm{FMBC}$ and (c) $\mathrm{Zn}$ (II)- FMBC in TrisHCl buffer (pH 7.2) at $25^{\circ} \mathrm{C}$. Arrow ( $\downarrow$ ) shows the emission intensity decreases upon increasing concentration of the complexes. Inset: Stern-Volmer plots (I); Scatchard plots (II).

Based on the above data the following structure can be tentatively assigned to the metal complexes (Figure 5).

\subsection{Biological studies}

3.6a Antibacterial and antifungal activity: The microbial activity of the ligand (FMBC) and its metal complexes were studied by the disk diffusion method (Figures 6 and 7) against the gram positive (Bacillus subtilis and Staphylococcus), gram negative bacteria ( $E$. coli and Pseudomonas) and fungal species (Sclerotium rolfsii and Macrophomina phaseolina). The activities of the compounds were compared with standard Streptomycin and Indofil. The results reveal (Tables S1 and S2 in Supplementary Information) the order of activity towards bacterial and fungal species as FMBC-Zn > FMBC-Cu $>$ FMBC-Ni $>$ FMBC, indicating more pronounced activity of metal chelates over ligand. This infers that the chelation facilitates the ability of a complex to cross a cell membrane as explained by Tweedy's chelation theory. ${ }^{35}$

3.6b DNA-binding studies: Absorption spectra studies: By using the Wolfe-Shimer equation, ${ }^{36}$ the binding constants $\left(\mathrm{K}_{\mathrm{b}}\right)$ of the metal complexes have been calculated from the data recorded using eq. 1

$[\mathrm{DNA}] /\left(\varepsilon_{\mathrm{a}}-\varepsilon_{\mathrm{f}}\right)=[\mathrm{DNA}] /\left(\varepsilon_{\mathrm{b}}-\varepsilon_{\mathrm{f}}\right)+1 / \mathrm{K}_{\mathrm{b}}\left(\varepsilon_{\mathrm{b}}-\varepsilon_{\mathrm{f}}\right)$

The apparent absorption coefficient $\varepsilon_{\mathrm{a}}$, corresponds to $A_{\text {obs }} /[$ metal complex $]$ and is calculated from absorbance value obtained after each successive addition of DNA in small increments, $\varepsilon_{\mathrm{f}}$ and $\varepsilon_{\mathrm{b}}$ correspond to the extinction coefficient of the free (unbound) and bound ligand. The $K_{b}$ value was calculated from the slope and the intercept values obtained from the plot of [DNA]/ 


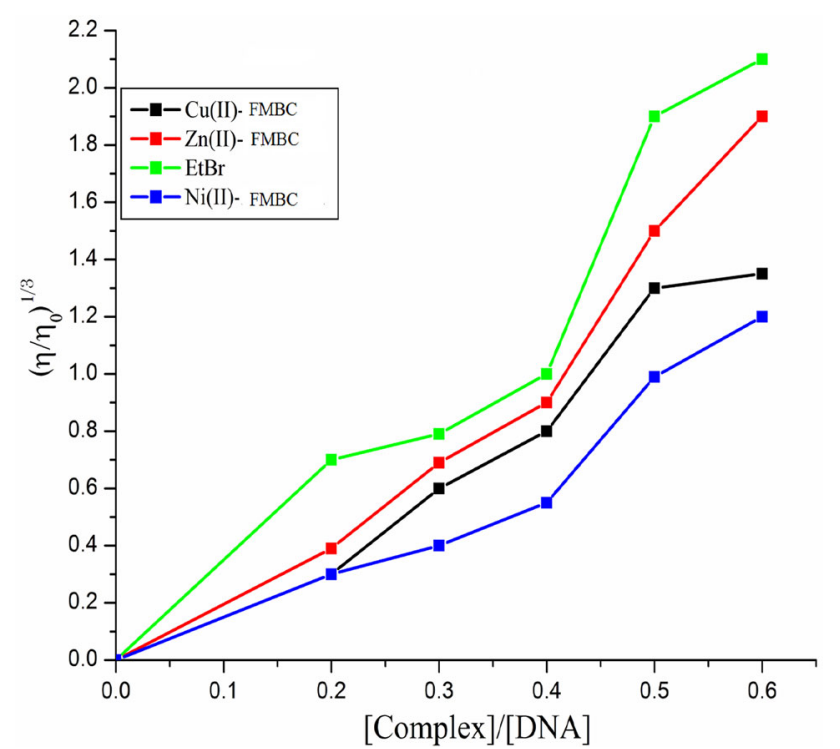

Figure 10. Plot of relative viscosity vs [Complex]/[DNA].

$\left(\varepsilon_{\mathrm{a}}-\varepsilon_{\mathrm{f}}\right)$ vs [DNA]. The $\varepsilon_{\mathrm{b}}$ corresponding to the extinction coefficient of the bound complex was calculated from slope value of plot. A red shift in wavelength of peak and decrease in absorbance (hypochromism) ${ }^{37}$ were observed, characteristic of binding mode of the complex to DNA through intercalation (Figure 8). Due to the presence of aromatic chromophore, hypochromic shift is observed which might facilitate the interaction of the complex with the CT-DNA bases via non-covalent $\pi-\pi^{*}$ interactions wherein $\pi^{*}$ orbital of the intercalated ligand in the complexes can couple with $\pi$ orbital of the DNA base pairs. The absorption spectral results (Table S14 in Supplementary Information) reveal relatively high binding constant of the $\mathrm{Zn}(\mathrm{II})$ complex indicating its greater binding affinity than the $\mathrm{Cu}$ (II) and $\mathrm{Ni}(\mathrm{II})$ complexes.

Fluorescence quenching studies The fluorescence quenching spectra of the compounds showed (Figure 9) that the newly synthesized compounds have the ability to displace EB from DNA-EB compound. The titration was carried out by the addition of the compounds in small increments which showed decrease in fluorescence intensity indicating the binding of the compound with DNA. The quenching constant was calculated by using Stern-Volmer ${ }^{38}$ equation:

$\mathrm{I}_{0} / \mathrm{I}=1+\mathrm{K}_{\mathrm{SV}}[\mathrm{r}]$

Where, $\mathrm{I}_{0}$ and $\mathrm{I}$ are the fluorescence intensities in the absence and presence of complexes, respectively, $\mathrm{K}_{\mathrm{SV}}$ is the Stern-Volmer constant, and $[\mathrm{r}]$ is the concentration of the compound. The fluorescence intensity data can also be used to determine the apparent binding constant

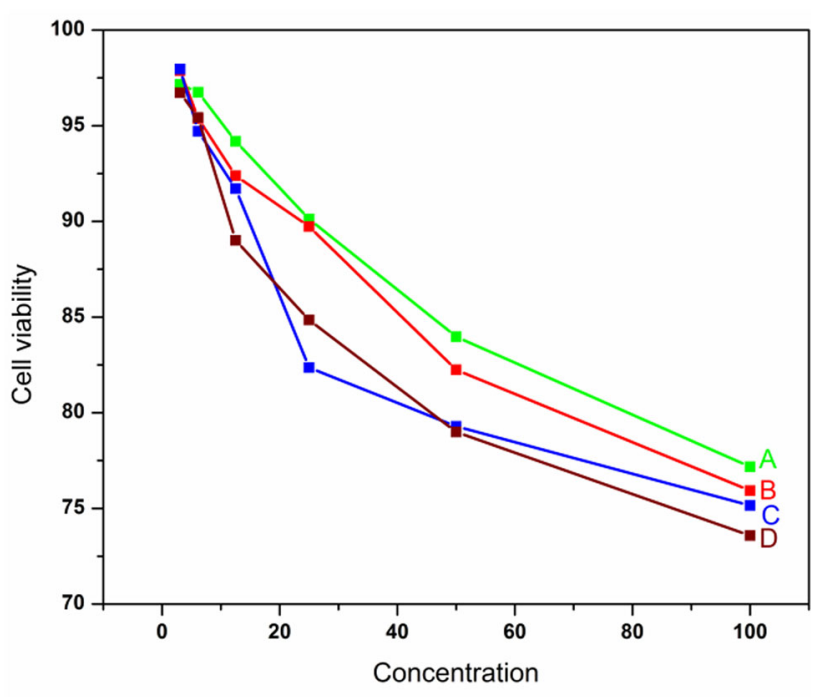

Figure 11. Effect of concentration $(\mu \mathrm{M})$ on cell viability of HeLa (Cervical Cancer) cell. A: FMBC B: Cu(II)-FMBC, C: Ni(II) -FMBC and D: Zn(II) -FMBC.

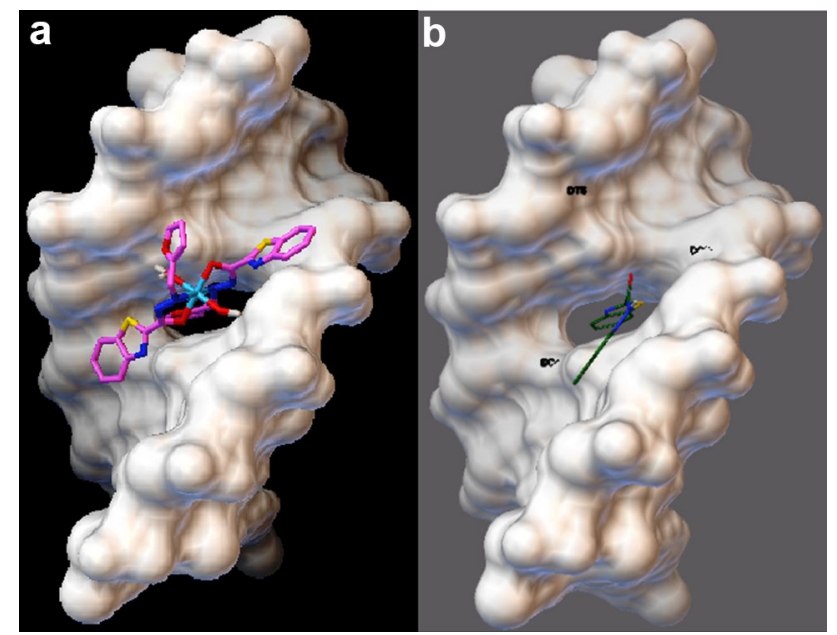

Figure 12. Dockpose of (a) $\mathrm{Zn}$ (II) complex and (b) Ligand at intercalation site of DNA. DNA is shown in molecular surface form.

$\left(\mathrm{K}_{\mathrm{b}}\right)$ and the number of binding sites (n) for the complex by the following equation: ${ }^{39}$

$\log \left[\left(\mathrm{F}_{0}-\mathrm{F}\right) / \mathrm{F}\right]=\log \mathrm{K}_{\mathrm{b}}+\mathrm{n} \log [\mathrm{Q}]$

From the plot of $\log \left[\left(\mathrm{F}_{0}-\mathrm{F}\right) / \mathrm{F}\right]$ versus $\log [\mathrm{Q}]$, binding stoichiometry $(\mathrm{n})$ has been obtained and binding constant $\left(\mathrm{K}_{\mathrm{b}}\right)$ from the slope and intercept values. The Stern-Volmer constant (Ksv), binding constant $\left(\mathrm{K}_{\mathrm{b}}\right)$ values and number of binding sites (n) of the metal complexes estimated using equations 2 and 3 are listed in (Table $\mathrm{S} 3$ in Supplementary Information). The $\mathrm{K}_{\mathrm{b}}$ values estimated by both absorption and fluorescent titrations are in good agreement. 

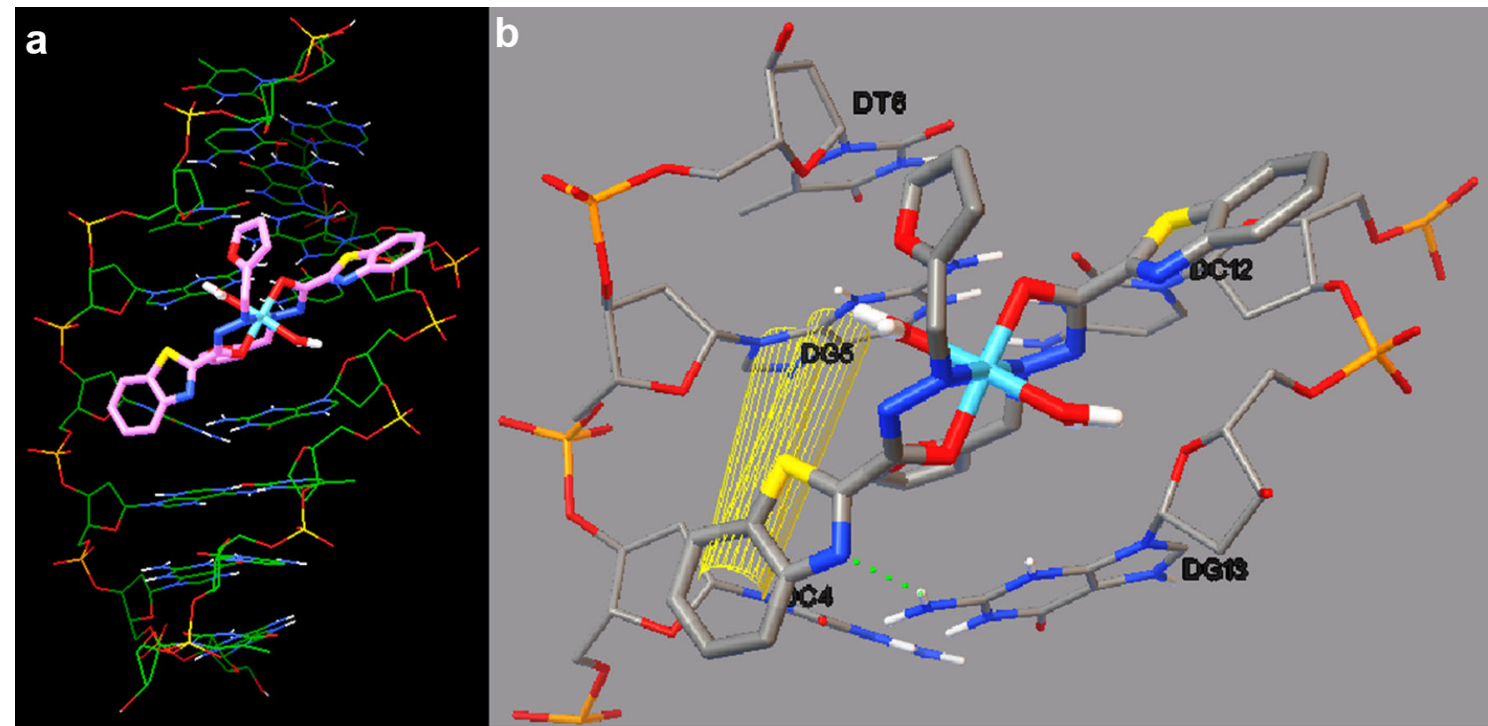

Figure 13. Dock pose of $\mathrm{Zn}$ (II) complex showing hydrogen bond interaction with G13 of DNA strand and $\pi-\pi$ stacking interaction with G5. (a) full view; (b) enlarged view.
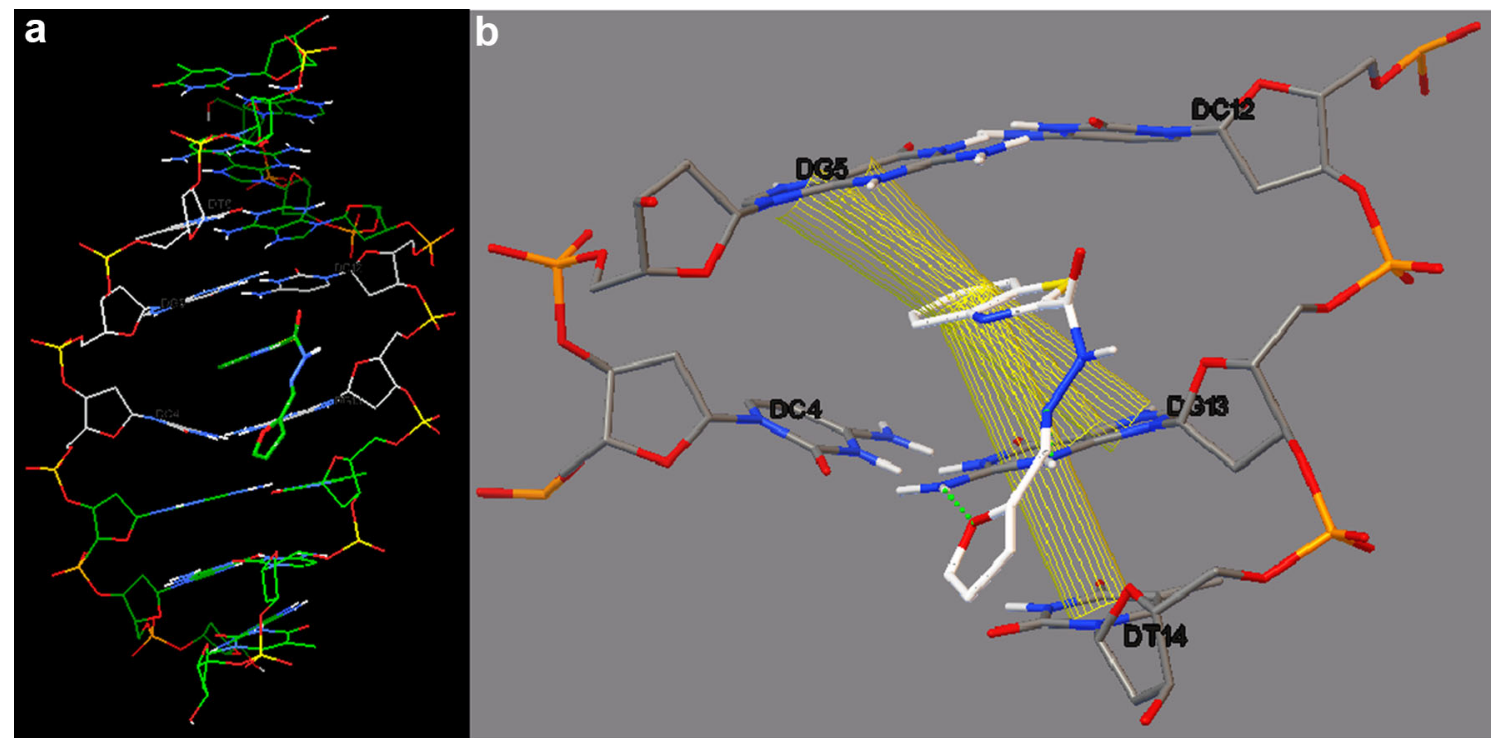

Figure 14. Dock pose of ligand showing hydrogen bond interaction with G13 of DNA strand and $\pi-\pi$ interaction with G5, G13 and T14 bases. (a) full view; (b) enlarged view.

Viscosity Measurements To further clarify the interaction between the metal complex and DNA, viscosity measurements were carried out by keeping the concentration of DNA constant $(5 \mu \mathrm{M})$ and increasing the concentration of metal complex. It is known that a classical intercalation of a ligand into DNA causes a significant increase in the viscosity of a DNA solution due to an increase in the separation of the base pairs at the intercalative site and hence, an increase in the overall DNA molecular length. ${ }^{40,41}$ The result (Figure 10) suggests that these complexes intercalate between the base pairs of DNA and thus augment the results obtained for binding constants through absorption and fluorescence studies.

\subsection{Cytotoxicity}

Cytotoxicity of the synthesised compounds in varying concentrations (Figure 11) on cancer cells using HeLa cell lines showed that as the concentration of compound increased, the cell viability is decreased. Among the compunds studied, Zn(II)-FMBC (Table S4 in Supplementary Information) is more effective, while free FMBC exhibited less activity. 


\subsection{DNA docking}

Docking of FMBC and its metal complexes into DNA showed hydrogen bonding interaction with G13 (Figure 12). The interaction of FMBC with DNA is distinct compared to its metal complexes. It has been observed that in the complexes the furan ring occupies the intercalation site and benzothiazole group at groove region resulting in higher hydrophobic interactions while in FMBC, merely benzothiazole ring is at the intercalation site with no moiety at the groove. The dock score and inhibition constant values which are the parameters to ascertain binding affinity infer that metal complexes have better binding affinity than free ligand FMBC. The greater binding affinity of complexes is due to the formation of hydrogen bond with G13 (Figures 13 and 14) and $\pi-\pi$ interaction with G5. Docking results are in accordance of experimental anticancer studies of the compounds wherein the ligand showed lower activity compared to the metal complexes. Computational DNA binding energy (dock score, Table S5 in Supplementary Information) of the metal complexes follow the experimental trend of DNA binding constant $\left(\mathrm{K}_{\mathrm{b}}\right)$ wherein better binding $\mathrm{Zn}(\mathrm{II})$ complex showed more negative dock score of $-8.41 \mathrm{kcal} / \mathrm{mol}$ followed by $\mathrm{Cu}(\mathrm{II})$ and $\mathrm{Ni}(\mathrm{II})$ complexes.

\section{Conclusions}

The spectro-analytical data obtained for title compound and its metal $(\mathrm{Cu}$ (II), $\mathrm{Zn}(\mathrm{II})$ and $\mathrm{Ni}$ (II)) complexes were used to establish the geometrical structure and properties. The molecular modeling studies were carried out to infer the electrostatic potentials and energies of frontier orbitals. The results of antimicrobial studies revealed that the complexes exhibit slightly higher activity than the free ligand. The DNA binding studies suggested that the metal complexes bind to CT-DNA through intercalation mode, which is further confirmed by molecular docking. The relatively lower $\mathrm{IC}_{50}$ values calculated from cytotoxicity studies for the metal complexes compared to free ligand reveal the greater potent activity of the metal complexes against HeLa cells.

\section{Supplementary Information (SI)}

Spectral (Mass, IR, NMR), pH titration curves (Figure S4 (a) \& (b)), IR of the complexes (Figures S5-S7), TGA (Figure S8), SEM and EDX images (Figures S9 \& S10) and ESR (Figure S11) and Tables (S1 to S5) are given as Supplementary information, available at www.ias.ac.in/chemsci.

\section{Acknowledgements}

We express our gratitude to Department of Chemistry, Nizam College, Basheerbagh, Osmania University for providing lab facilities for synthesis and Department of Chemistry, Osmania University for providing Instrumentation Lab Facilities, and the Central Facilities for Research \& Development (CFRD) for recording IR and NMR Spectra. We acknowledge Sophisticated Analytical Instrument Facility (SAIF), IIT Bombay for recording ESR spectra and Biogenics Research and Training Center, Hubli, Karnataka for cytotoxicity studies. We are deeply thankful for the generous funding extended from UGC-FAR and DST-PURSE Projects.

\section{References}

1. Cozzi P G 2004 Metal-Salen Schiff base complexes in catalysis: practical aspects Chem. Soc. Rev. 33410

2. Ravi M, Kishan Prasad C H, Ushaiah B, Ravi Kumar E, Shyam P, Rajanna A and Sarala Devi C H 2015 A Study on Spectro-Analytical Aspects, DNA -Interaction, Photo-Cleavage, Radical Scavenging, Cytotoxic Activities, Antibacterial and Docking Properties of 3-(1-(6methoxybenzo [d] thiazol-2-ylimino) ethyl)-6-methyl3H-pyran-2, 4-dione and its Metal Complexes J. Fluoresc. 251279

3. Kishan Prasad C H, Ravi M, Ushaiah B, Srinu V, Ravi Kumar E and Sarala Devi C H 2016 Synthesis, characterization, DNA interactions, DNA cleavage, radical scavenging activity, antibacterial, anti-proliferative and docking studies of new transition metal complexes $J$. Fluoresc. 26189

4. Aparup P, Soumen M, Apurba B, Soumen M, Horst P and Subal Chandra Manna 2016 RSC Adv. 66048

5. Delaney S, Pascaly M, Bhattacharya P K, Han K and Barton J K 2002 Oxidative damage by ruthenium complexes containing the dipyridophenazine ligand or its derivatives a focus on intercalation Inorg. Chem. 411966

6. Bergeron K L, Murphy E L, Olulade M, Muñoz L D, Williams J C and Almeida K H 2009 Arylphosphonium salts interact with DNA to modulate cytotoxicity Mutat. Res. 673141

7. Strekowski L and Wilson B 2007 Noncovalent interactions with DNA: An overview Mutat. Res-Fund. Mol. M. 6233

8. Palchaudhuri R and Hergenrother P 2007 DNA as a target for anticancer compounds: methods to determine the mode of binding and the mechanism of action J. Curr. Opin. Biotech. 18497

9. Yadav P S, Dev P and Senthilkumar G P 2011 Benzothiazole Different methods of synthesis and diverse biological activities Int. J. Pharm. Sci. Res. 301

10. Akhtar T, Hameed S, Al-Masoudi N, Loddo R and Colla P L 2008 In vitro antitumor and antiviral activities of new benzothiazole and 1,3,4-oxadiazole-2-thione derivatives Acta Pharma 58135

11. Bradshaw T D, Wrigley S, Shi D F, Schultz R J and Stevens M F G 19982 (4-aminophenyl) benzothiazoles: novel agents with selective profiles of in vitroantitumor activity Br. J. Cancer 77745 
12. Pranav P, Das S K, Shafaat K and Anand J P 2012 Evaluation of N-(6-Chloro benzothiazol-2-yl)-2-(substituted amino) Acetamide for its antibacterial activity Int. J. Pharm. Sci. Res. 32669

13. Devmurari V P, Shivanand P, Goyani M B, Nandanwar R R, Jivani N P and Perumal P 2010 Synthesis and Anticancer Activity of Some Novel 2-Substituted Benzothiazole Derivatives Int. J. Chemtech Res. 2681

14. Kamal A, Reddy K S, Khan M, Shetti R, Ramaiah M, Pushpavalli S N, Srinivas C, Bhadra M P, Chourasia M, Sastry G N, Juvekar A, Zingde S and Barkume M 2010 Synthesis, DNA-binding ability and anticancer activity of benzothiazole/benzoxazolepyrrolo[2,1-c][1,4] benzodiazepine conjugates Bioorg. Med. Chem. 184747

15. Shi X H, Wang Z, Xia Y, Ye T H, Deng M, Xu Y Z, Wei Y $Q$ and Yu L T 2012 Synthesis and biological evalution of novel benzothiazole-2-thiolderivatives as potential anticancer agent Molecule 173933

16. Suresh S H, Venkateshwara R J and Jayaveera K N 2010 Synthesis of 4-(2'-substituted benzothiazoles)5-mercapto-3-(substituted)-1,2,4-triazole derivatives for possible antimicrobiologicalactivities Res. J. Pharma Biol. Chem. Sci. 1635

17. Alang G, Kaur R, Kaur G, Singh A and Singla P 2010 Synthesis and antibacterial activity of some new benzothiazole derivatives Acta Pharm. Sci. 52213

18. Imramovsky A, Pejchal V, Pankova S S, Vorcakova K, Jampilek J, Vanco J, Simunek P, Kralovec K, Bruckova L, Mandikova J and Trejtnar F 2013 Synthesis and in vitro evaluation of new derivatives of 2 -substituted6-fluorobenzo[d] thiazoles as cholinesterase inhibitors Bioorg. Med. Chem. 21735

19. Sathe B S, Jayachandran E, Jagtap V A and Sreenivasa G M 2011 Anthelmintic activity of newly synthesized moieties of fluorobenzothiazole Schiff's bases Res. J. Pharma Biol. Chem. Sci. 2510

20. Pattan S, Suresh C, Pujar V, Reddy V, Rasal V and Koti B 2005 Synthesis and antidiabetic activity of 2-amino [5(4sulphonyl benzylidine)-2,4-thiazolidinenone]-7-chloro6-fluro benzothiazole Indian J. Chem. 44B 2404

21. Narsimha N, Ranjithreddy P, Jaheer M D, Aparna B and Saraladevi C H 2015 Synthesis, Characterization and Biological Studies of Novel (16Z)-1-ethyl-1, 4-dihydroN'-(1-(3, 4- dihydro-6-methyl-2, 4-dioxo-2H-pyran3-yl)ethylidene)-7-methyl-4-oxo-1, 8-naphthyridine 3carbohydrazide) and its $\mathrm{Cu}$ (II), $\mathrm{Ni}$ (II) and Co (II) Complexes Int. J. Res. Pharm. Chem. 5615

22. Aparna A V, Sudeepa K, Raghavaiah P and Sarala Devi C H 2013 Spectro-analytical-ray diffraction and computational studies on N-[(2-hydroxyphenyl) methylidene] acetohydrazide and its copper complex J. Indian Chem. Soc. 9033

23. Hyperchem 2003 Hypercube, Inc.

24. Searle M S, Maynard A J and Williams H E 2003 DNA recognition by the anthracycline antibiotic respinomycin D: NMR structure of the intercalation complex with the (AGACGTCT)2 Org. Biomol. Chem. 160

25. Michel F and Sanner 1999 Python: A Programming Language for Software Integration and Development J. Mol. Graphics Mod. 1757

26. Campaingne E 1958 Reaction of Diethyl Oxalate with Some ortho-Substituted Anilines J. Org. Chem. 231344
27. Campainge E, Thompson R L and Vanwerth J E 1959 Some Heterocyclic Aldehyde Thiosemicarbazones Possing Anti-viral Activity J. Med. Chem. 1577

28. Shakir M, Summaiya H, FazleAlam M D and Hina Y 2016 Molecular hybridization approach of bio-potent $\mathrm{Cu}(\mathrm{II}) / \mathrm{Zn}$ (II) complexes derived from N, O donor bidentate imine scaffolds: Synthesis, spectral, human serum albumin binding, antioxidant and antibacterial studies $J$. Photochem. Photobiol. 16596

29. Nagesh G Y and Mruthyunjaya swamy B H M 2015 Synthesis, characterization and biological relevance of some metal (II) complexes with oxygen, nitrogen and oxygen (ONO) donor Schiff base ligand derived from thiazole and 2-hydroxy-1-naphthaldehyde J. Mol. Struct. 1085198

30. Nakamoto K 1997 Infrared and Raman Spectra of Inorganic and Coordination Compounds $5^{\text {th }}$ edn. (New York: Wiley-Interscience)

31. Bellamy L J 1980 The Infrared Spectra of Complex Molecules $2^{\text {nd }}$ ed. (London: Chapmann and Hall)

32. Naeimi H and Moradian M 2010 Synthesis and characterization of nitro-Schiff bases derived from 5-nitrosalicylaldehyde and various diamines and their complexes of Co(II) J. Coord. Chem. 63156

33. Kavitha P et al 2013 Synthesis, structural characterization, fluorescence, antimicrobial, antioxidant and DNA cleavage studies of $\mathrm{Cu}(\mathrm{II})$ complexes of formyl chromone Schiff bases Spectrochim. Acta A 102159

34. Sebastian M, Arun V, Robinson P P, Varghese A A, Abraham R, Suresh E and Yusuff K K M 2010 Synthesis, structural characterization and catalytic activity study of $\mathrm{Mn}$ (II), $\mathrm{Fe}(\mathrm{III}), \mathrm{Ni}(\mathrm{II}), \mathrm{Cu}(\mathrm{II})$ and $\mathrm{Zn}$ (II) complexes of quinoxaline-2-carboxalidine-2-amino-5methylphenol: Crystal structure of the nickel(II) complex Polyhedron 293014

35. Tweedy B G 1964 Plant extracts with metal ions as potential antimicrobial agents Phytopathology 55910

36. Lu J, Sun Q, Li J L, Gu W, Tianab J L, Liuab X and Yan S P 2013 Synthesis, characterization, and DNA-binding of two new Cd(II) complexes with 8[(2-pyridylmethyl)amino]-quinoline J. Coord. Chem. 66 3280

37. Liu H K and Sadler P J 2011 Metal complexes as DNA intercalators Acc. Chem. Res. 44349

38. Stern O and Volmer M 1919 Über die Abklingzeit der Fluoreszenz Physik. Zeitschr. 20183

39. Tabrizi L, McArdle P, Erxleben A and Chiniforoshan H 2015 Nickel (II) and cobalt (II) complexes of lidocaine Synthesis, structure and comparative in vitro evaluations of biological perspectives Eur. J. Med. Chem. 103516

40. Tarui M, Doi M, Ishida T, Inoue M, Nakaike S and Kitamura K 1994 DNA-binding characterization of a novel anti-tumourbenzo[a]- phenazine derivative NC182 spectroscopic and viscometric studies Biochem. J. 304271

41. Guo H, Lu J, Ruan Z, Zhang Y, Liu Y, Zang L, Jiang J and Huang J 2012 Synthesis, DNA-binding, cytotoxicity, and cleavage studies of unsymmetrical oxovanadium complexes J. Coord. Chem. 65191 